\title{
Approaches to assessing the effectiveness of the team's performance in international athletics competitions (on the example of endurance)
}

\author{
Rykalov Iu.V. ${ }^{1}$, Goncharova N.M. ${ }^{2}$ \\ ${ }^{1}$ Secondary school №168 \\ ${ }^{2}$ National University of Physical Education and Sport of Ukraine
}

DOI: https://doi.org/10.34142/HSR.2020.06.02.08

\begin{abstract}
Abstrakt
The aim: theoretical substantiation and development of approaches to assessing the effectiveness of the results of the sports team's performance in international athletics competitions (on the example of endurance).

Material and methods: theoretical analysis and generalization of scientific and methodological literature and information of the Internet, data of information databases of athletics (Tilastopaja), (All-Athletics), printed and electronic sources of the Association of Track \& Field Statisticians- ATFS ), the official website of the European Athletics Association (EAA), the Federation of Athletics of Ukraine, systematization, content analysis. An analysis of the results of competitive activities of athletes $(n=297)$ of the best thirteen European teams that participated in the XXIV European Athletics Championships (Berlin, 2018) in endurance and have gold awards. The criteria that allow to expand the approaches to assessing the effectiveness of the performance of the full team were considered. Results. The performance of thirteen best teams in athletics in endurance at the XXIV European Athletics Championships (Berlin, 2018) was analyzed. The obtained data allowed us to conclude that in order to create an objective assessment of the team's performance in athletics, it is not enough to take into account only the number of medals won and the places occupied by the team's athletes in the top eight. When determining the effectiveness of team performance in endurance classes, according to the existing evaluation system, medals were awarded to $2 \%$ to $33 \%$ of athletes from the total team, and places in the top eight were occupied by 18 to $75 \%$ of athletes. Conclusions. When evaluating the effectiveness of a sports team, you need to take into account a number of criteria that will create a diverse assessment of the performance of the sports team, which includes evaluation as a criterion - the performance of athletes at the level of personal achievement.
\end{abstract}

Key words: athletics, European Championship, efficiency, team, approaches to evaluation.

\section{Анотація}

Рикалов Ю.В., Гончарова Н.М. Підходи до оцінки ефективності результатів виступу команди у міжнародних змаганнях з легкої атлетики (на прикладі видів на витривалість)

Мета роботи - теоретичне обґрунтування та розробка підходів до оцінки ефективності результатів виступу спортивної команди у міжнародних змаганнях з легкої атлетики (на прикладі видів витривалості).

Матеріал і методи: теоретичний аналіз і узагальнення науково-методичної літератури та інформації мережі Internet, даних інформаційних баз легкої атлетики (Tilastopaja), (All-Athletics), друкованих та електронних джерел Асоціації статистиків з легкої атлетики (Association of Track \& Field Statisticians- ATFS), офіційного сайту Європейської легкоатлетичної асоціації (EAA), Федерації легкої атлетики України, систематизація, контент-аналіз. Проведено аналіз результатів змагальної діяльності спортсменів ( $n=297)$ кращих тринадцяти європейських команд, які приймали участь у XXIV чемпіонаті Європи з легкої атлетики (Берлін, 2018) в видах витривалості та мають в своєму активі золоті нагороди. Розглядались критерії, які дозволяють розширити підходи до оцінки ефективності виступу повного складу команди.

Результати. Проведено аналіз виступу тринадцяти кращих команд з легкої атлетики у видах витривалості на XXIV Чемпіонаті Європи з легкої атлетики (Берлін, 2018 р). Отримані дані дозволили зробити висновок про те, що для створення об'єктивного оцінювання результативності виступу команди у легкій атлетиці недостатньо враховувати тільки кількість завойованих медалей та зайняті місця спортсменами команди у першій вісімці. Під час визначення результативності загальнокомандного виступу спортсменів у видах на витривалість, за існуючою системою оцінки, що медалі отримували від 2 \% до 33 \% атлетів від загального складу команди, а місця в першій вісімці займали від 18 до 75 \% атлетів.

Висновки. Під час оцінки ефективності спортивної команди потрібно враховувати більшу кількість критеріїв, які дозволять створити різнопланову оцінку виступу спортивної команди, що включає оцінку в якості критерію - виступ спортсменів на рівні особистого досягнення.

Ключові слова: легка атлетика, чемпіонат Європи, ефективність, команда, підходи до оцінювання.

\section{Аннотация}

Рыкалов Ю.В., Гончарова Н.Н. Подходы к оценке эффективности результатов выступления команды в международных соревнованиях по легкой атлетике (на примере видов на выносливость)

Цель: теоретическое обоснование и разработка подходов к оценке эффективности результатов выступления спортивной команды в международных соревнованиях по легкой атлетике (на примере видов выносливости)

Материал и методы: теоретический анализ и обобщение научно-методической литературы и информации сети Internet, данных информационных баз легкой атлетике (Tilastopaja), (All-Athletics), печатных и электронных источников Ассоциации статистиков по легкой атлетике (Association of Track \& Field Statisticians- ATFS), официального сайта Европейской легкоатлетической ассоциации (EAA), Федерации легкой атлетики Украины, систематизация, контент-анализ. Проведен анализ результатов соревновательной деятельности спортсменов ( $\mathrm{n}=297)$ лучших тринадцати европейских команд, которые принимали участие в XXIV чемпионате Европы по легкой атлетике (Берлин, 2018) в видах выносливости и имеют в своем активе золотые награды. Рассматривались критерии, которые позволяют расширить подходы к оценке эффективности выступления полного состава команды.

Результаты. Проведен анализ выступления тринадцати лучших команд по легкой атлетике в видах выносливости на XXIV Чемпионате Европы по легкой атлетике (Берлин, 2018 г.). Полученные данные позволили сделать вывод о том, что для создания объективной оценке результативности выступления команды в легкой атлетике недостаточно учитывать только количество завоеванных медалей и занятые места спортсменами команды в первой восьмерке. При определении результативности общекомандного выступления спортсменов в видах на выносливость, по существующей системой оценки, медали получали от 2\% до 33\% атлетов от общего состава команды, а места в первой восьмерке занимали от 18 до $75 \%$ атлетов. Выводы. При оценке эффективности спортивной команды нужно учитывать большее количество критериев, которые позволят создать разноплановую оценку выступления спортивной команды, включая оценку в качестве критерия - выступление спортсменов на уровне личного достижения.

Ключевые слова: легкая атлетика, чемпионат Европы, эффективность, команда, подходы к оценке. 


\section{Introduction}

An important part of the management of training and competitive activities of athletes is a system of integrated control, through which you can assess the effectiveness of the chosen direction of the training process [1]. Properly organized system of control of training and competitive activities of athletes is the basis of sports selection of promising athletes, evaluation of effectiveness and the need for correction in the training process of athletes $[1,2]$.

Analysis of scientific and methodological literature allows us to say the great interest of scientists in the implementation of the control function in the training process of athletes [2, 3, 4]. The problem of finding effective approaches to assessing the results of participation in the competitive activities of the athlete and the team as a whole has always aroused increased interest among sports professionals $[2,4,5]$. Examples from the practice of evaluating competitive activity in martial arts confirm the existence of certain criteria for evaluating effectiveness. Among such criteria in the fight are determined: activity, efficiency, effectiveness, victory, variability, frequency of application of technical and tactical actions of the athlete, which later according to certain formulas of communication acquire numerical value [6]. Assessing the effectiveness of competitive activities in boxing also takes into account the effectiveness and variety of techniques, the degree of activity of the athlete, the number of defensive actions in response to attacking actions of the opponent, the ability to anticipate the actions of the opponent, the ability to manage psychoemotional state [7]. The experience of practical activity in sports games is saturated with methodical approaches to assessing the effectiveness of the athlete and the sports team in general $[8,9,10,11]$.

In his work SM Wojciechowski [12] developed a coefficient of "getting in shape" to determine the timing of "sports uniform" as one of the criteria for assessing the effectiveness of the athlete's performance in competitions, taking into account the dynamics of changes in athlete's performance during the competition period.

The substantiation of an estimation of a condition of a sports form and definition of border for each zone of "sports form" was made by professor LP Matveev [2]:

1 - the zone of the best and close to them results - within 1,0-1,5\% deviation from the best personal result;

2 - zone of high results - in the range of 2.5$4.0 \%$;

3 - zone of reduced results, deviation above $4.0 \%$

Domestic sports experts [4] studied the results shown by athletes at official international starts compared to their personal records and the best results of the season, and found that only $15 \%$ of Ukrainian athletes reached the level of highest readiness for the 2016 Olympic Games and 2017 World Championships year. The research conducted by the authors [4] allowed us to summarize the need to improve the model of direct preparation for the main competitions, which will allow athletes to reach the level of their best achievements in the main competitions in $60 \%$ of cases.

Based on the analysis of scientific and methodological literature, comprehensive analysis of the results of competitive activities of athletes, practical experience in athletics, it was found that the most common approaches to assessing the effectiveness of team performance are won medals (Medal Place) and indicators of points per place in the first eight (Placing Table). This approach is used by international athletics federations (IAAF and EAA) in summing up the team standings at many world and European championships.

An example of using this system to assess the effectiveness of the team's performance in athletics are the results of the best teams at the XXIV European Athletics Championships (Berlin, 2018) in endurance in the medal standings (Medal Place) (Table 1).

Medal test of sports teams at the XXIV European Athletics Championships (Berlin, 2018)

\begin{tabular}{cccccc}
\hline Place & Team & Gold & Silver & Bronze & Total \\
\hline 1. & Spain & 2 & $2+1(\mathrm{k})$ & $1+1(\mathrm{k})$ & 7 \\
\hline 2. & France & 2 & 2 & 2 & 6 \\
\hline 3. & Norway & 2 & 1 & 1 & 4 \\
\hline 4. & Ukraine ${ }^{*}$ & 2 & - & 2 & 4 \\
\hline 5. & Belarus & $1+1(\mathrm{k})$ & 0 & 1 & 3 \\
\hline 6. & Poland & 1 & 2 & 0 & 3 \\
\hline 7. & Italy & $1(\mathrm{k})$ & $1(\mathrm{k})$ & 4 & 6 \\
\hline 8. & United Kingdom & 1 & 1 & 2 & 4 \\
\hline 9. & Netherlands & 1 & 1 & 0 & 2 \\
\hline$=9$. & Belgium & 1 & 1 & 0 & 2 \\
\hline 11. & Germany & 1 & 0 & 0 & 1 \\
\hline$=11$. & Israel & 1 & 0 & 0 & 1 \\
\hline$=11$. & Portugal & 1 & 0 & 0 & 1 \\
\hline
\end{tabular}

Note: $\mathrm{k}$ - team competition in marathon running (Marathon Cup); ${ }^{*}$ - without taking into account the results of two suspended athletes (A. Tsviliy, V. Vitovshchyk in $50 \mathrm{~km}$ walking) [13] 
Team results of the XXIV European Athletics Championships (Berlin, 2018) in endurance points for points taken from 1 to 8
(Placing Table), taking into account the team standings in the marathon.

Table 2

The results of the performance of sports teams following the XXIV European Athletics Championships (Berlin, 2018)

\begin{tabular}{|c|c|c|c|c|c|c|c|c|c|c|}
\hline & \multirow[t]{2}{*}{ Country } & \multicolumn{8}{|c|}{ Athlete's place, number of athletes } & \multirow[t]{2}{*}{$\begin{array}{c}\text { Number } \\
\text { points }\end{array}$} \\
\hline & & 1 & 2 & 3 & 4 & 5 & 6 & 7 & 8 & \\
\hline 1. & Spain & $2(16)$ & $3(21)$ & $2(12)$ & $1(5)$ & $1(4)$ & $5(15)$ & $1(2)$ & $1(1)$ & 76 \\
\hline 2. & United Kingdom & $1(8)$ & $1(7)$ & $2(12)$ & $2(10)$ & $5(20)$ & $2(6)$ & $1(2)$ & $1(1)$ & 66 \\
\hline 3. & Italy & $1(8)$ & $1(7)$ & $4(24)$ & $2(10)$ & $1(4)$ & $1(3)$ & - & $2(2)$ & 58 \\
\hline 4. & France & $2(16)$ & $2(14)$ & $2(12)$ & $1(5)$ & - & - & - & $1(1)$ & 48 \\
\hline 5. & Poland & $1(8)$ & $2(14)$ & - & $1(5)$ & $3(12)$ & $1(3)$ & $2(4)$ & - & 46 \\
\hline 6. & Norway & $2(16)$ & $1(7)$ & $1(6)$ & $2(10)$ & - & - & - & - & 39 \\
\hline 7. & Germany & $1(8)$ & - & - & $2(10)$ & $2(8)$ & $1(3)$ & $2(4)$ & $2(2)$ & 35 \\
\hline$=8$. & Belarus & $2(16)$ & - & $1(6)$ & $1(5)$ & $1(4)$ & - & - & $2(2)$ & 33 \\
\hline$=8$ & Ukraine $^{*}$ & $2(16)$ & - & $2(12)$ & - & - & - & $2(4)$ & $1(1)$ & 33 \\
\hline 10. & Netherlands & $1(8)$ & $1(7)$ & - & - & - & $1(3)$ & $1(2)$ & - & 20 \\
\hline 11. & Belgium & $1(8)$ & $1(7)$ & - & - & - & $1(3)$ & & $1(1)$ & 19 \\
\hline 12. & Israel & $1(8)$ & - & - & - & $1(4)$ & - & $1(2)$ & - & 14 \\
\hline 13. & Portugal & $1(8)$ & - & - & - & - & $1(3)$ & - & $1(1)$ & 12 \\
\hline
\end{tabular}

Note: () - number of points (1st place - 8 points, 2 nd place -7 points, 3rd place -6 points, 4th place -5 points, 5 th place - 4 points, 6 th place -3 points, 7 th place -2 points, 8 place -1 point)

Analysis of the presented data (Tables 1,2), based on the use of only two evaluation criteria (number of medals and places occupied by athletes from 1 to 8), in our opinion, does not allow to qualitatively assess the effectiveness of athletes and direct work of specialists, who work with national teams. The main disadvantage of this approach is the lack of ability to assess the effectiveness of competitive activities of each athlete in the team.

The obtained results allow us to state that during the analysis of the performance of the best teams at the European Championship 2018 in Berlin, in the final evaluation of the performance of teams from different countries on the criterion of medal count, the results of $2 \%$ to $33 \%$ of athletes were taken into account. At the same time, according to the criterion of the number of athletes who took places in the top eight, $18 \%$ to $75 \%$ of athletes entered the test, ie from $25 \%$ to $82 \%$ of the results of team members remain unnoticed. Thus, the current approach to assessing the effectiveness of the team's performance does not allow to take into account the contribution of each team athlete to the overall result of the main competition of the year, which will not contribute to full analysis and professional identification of shortcomings and ways to improve.
The aim: theoretical substantiation and development of approaches to evaluation of efficiency of results of performance of a sports team in the international competitions in athletics (on an example of types of endurance).

\section{Material and methods}

Research methods: theoretical analysis and generalization of scientific and methodological literature and information of the Internet, data from athletics databases (Tilastopaja [14]), (AllAthletics), printed and electronic sources of the Association of Track \& Field Statisticians - ATFS [15]), the official website of the European Athletics Association (EAA) [16], the Athletics Federation of Ukraine [17] were conducted based on the need to summarize existing approaches to assessing the effectiveness of athletics teams and the results obtained during such assessment, systematization the obtained data and content analysis allowed to propose additions to the existing assessment approach.

\section{Organization of the study}

An analysis of the results of competitive activities of athletes $(n=297)$ of the best 13 
European teams that participated in the XXIV European Athletics Championships (Berlin, 2018) in endurance and have gold medals. Criteria were considered that allow to expand the approaches for assessing the effectiveness of the performance of the full team.

\section{Results}

An analysis of the results of competitive activities of the best athletes in Europe, representatives of endurance at the XXIV European Athletics Championships, which took place from 06 to 12 August 2018 in the German capital Berlin.

1571 athletes from 50 countries $(826$ men and 745 women) took part in the European Athletics Championships, including 527 athletes $(33.5 \%$ of the total number of participants) from 44 countries (288 men and 239) competed in endurance. women).

For the first time in the history of the European Championships, women competed in the distance of $50 \mathrm{~km}$ in athletic walking, thus 18 sets of awards were drawn, in endurance classes (36\% of the total), 16 sets in individual competitions $(800 \mathrm{~m}$, $1500 \mathrm{~m}) .5000 \mathrm{~m}, 10000 \mathrm{~m}, 3000 \mathrm{~m}$ hurdles, marathon running and athletic walking $20 \mathrm{~km}, 50 \mathrm{~km}$ among men and women) and 2 sets in team competitions in marathon running (Marathon Cup).

The national team of Ukraine was represented in endurance by 31 athletes, the 4th indicator on the number of members (15 men and 16 women) is $35 \%$ of the total composition of the national team. At the European Championships, athletes from Ukraine of this group of species won 4 medals: two gold (N. Pryschepa, $800 \mathrm{~m}$ run, M. Zakalnytsky, $50 \mathrm{~km}$ sport walking) and two bronze (O. Lyakhova, $800 \mathrm{~m}$ run, H. Yudkina, athletic walking for $50 \mathrm{~km}$ ). Performances of Ukrainian athletes were the best during the years of Independence of Ukraine, which corresponded to the fourth team place in endurance after Spain, France, Norway (by the criterion of medal count).

According to the second approach to assessing the team's performance (Placing table), which is used by the European Athletics Association (EAA), the Ukrainian endurance team has the eighth indicator. Unfortunately, it should be noted that in addition to four medals at the European Championships, our athletes have only 3 results from 4th to 8th place, including one result in the individual competition (N. Borovska - 7th place, walking 20 $\mathrm{km})$ and two results in team competitions. from marathon running.
Among the thirty-one representatives of the national team of Ukraine in endurance, only seven athletes $(22.6 \%)$ showed their best result, namely four personal achievements and three best results of the season. According to this indicator, the team results of Ukrainian athletes corresponded to the sixth position among the best teams in Europe. Instead, the first place was taken by the teams of Israel, in which $75 \%$ of athletes showed personal achievements, the second place was taken by the team of the Republic of Belarus $-41.7 \%$ and the third place was taken by Italy - $30 \%$, respectively.

In the team competitions in marathon running, the women's national team of Ukraine was represented by four athletes and took seventh place among eleven teams. Representatives of the men's national team of Ukraine in the marathon consisted of five athletes and took eighth place among twelve teams from European countries.

Analyzing the quality of performance of athletes in marathon running, it should be noted that the team standings included the amount of time of the three best athletes from each country. Unfortunately, the performances of Ukrainian marathon runners did not correspond to the best personal achievements of athletes, only D. Mykhailova showed her best result in the season $(11.1 \%$ of athletes from the total number of Ukrainian marathon runners), so the results shown by athletes did not allow to make a decent competition to the winners of the competition. It should also be noted that the personal results of the representatives of the men's national team of Ukraine in the marathon run potentially allowed to do.

Summarizing the results of the performance of athletes in endurance at the European Championships in Berlin, the main emphasis was placed on complementing approaches to assessing the performance of sports teams, which, in our opinion, will assess and analyze the achievements of all representatives, not just the top eight athletes. . In the process of analysis, the performances of all athletes from different countries were systematized (Table 3), without taking into account the performance of athletes in marathon running.

Thus, among the thirteen best sports teams that took part in the European Championships in endurance, the total number of representatives was two hundred and ninety-seven athletes $(56.4 \%$ of the total number of athletes who participated in endurance at the championship) with a total number of starts three hundred and thirteen times in different endurance disciplines, ie sixteen athletes $(5.4 \%)$ out of two hundred and ninety-seven participated in two types of competitions. 
Table 3

The results of the success of the performance of full-fledged sports teams following the results of the XXIV European Athletics Championships (Berlin, 2018)

\begin{tabular}{|c|c|c|c|c|c|c|c|}
\hline \multirow{3}{*}{ Place } & \multirow{3}{*}{ Team } & \multirow{3}{*}{$\begin{array}{c}\text { Number } \\
\text { of } \\
\text { participants }\end{array}$} & \multirow{3}{*}{$\begin{array}{l}\text { Number } \\
\text { of starts made } \\
\text { by participants }\end{array}$} & \multicolumn{3}{|c|}{$\begin{array}{c}\text { Place of the athlete, number of } \\
\text { athletes }\end{array}$} & \multirow{2}{*}{$\begin{array}{l}\text { DNF, DQ } \\
\text { DNS }\end{array}$} \\
\hline & & & & $1-8$ & $9-16$ & $\begin{array}{l}17 \text { and } \\
\text { below }\end{array}$ & \\
\hline & & & & $\%$ & $\%$ & $\%$ & $\%$ \\
\hline \multirow{2}{*}{1} & \multirow{2}{*}{ Israel } & \multirow{2}{*}{4} & \multirow{2}{*}{5} & 3 & - & 1 & 1 \\
\hline & & & & $60 \%$ & & $20 \%$ & $20 \%$ \\
\hline \multirow{2}{*}{2} & \multirow{2}{*}{ Belarus } & \multirow{2}{*}{12} & \multirow{2}{*}{14} & 6 & 2 & 4 & 2 \\
\hline & & & & $42,9 \%$ & $14,3 \%$ & $28,5 \%$ & $14,3 \%$ \\
\hline \multirow[b]{2}{*}{3} & \multirow{2}{*}{ Norway } & \multirow{2}{*}{12} & \multirow{2}{*}{14} & 6 & 3 & 3 & 2 \\
\hline & & & & $42,9 \%$ & $21,4 \%$ & $21,4 \%$ & $14,3 \%$ \\
\hline \multirow{2}{*}{4} & \multirow{2}{*}{ United Kingdom } & \multirow{2}{*}{35} & \multirow{2}{*}{35} & 14 & 13 & 4 & 4 \\
\hline & & & & $40 \%$ & $37,2 \%$ & $11,4 \%$ & $11,4 \%$ \\
\hline \multirow{2}{*}{5} & \multirow{2}{*}{ Netherlands } & \multirow{2}{*}{10} & \multirow{2}{*}{12} & 4 & 2 & 4 & 2 \\
\hline & & & & $33,3 \%$ & $16,7 \%$ & $33,3 \%$ & $16,7 \%$ \\
\hline \multirow{2}{*}{6} & \multirow{2}{*}{ Spain } & \multirow{2}{*}{42} & \multirow{2}{*}{43} & 14 & 17 & 8 & 4 \\
\hline & & & & $32,6 \%$ & $39,5 \%$ & $18,6 \%$ & $9,3 \%$ \\
\hline \multirow{2}{*}{7} & & & & 10 & 12 & 6 & 3 \\
\hline & Italy & 30 & 31 & $32,3 \%$ & $38,7 \%$ & $19,3 \%$ & $9,7 \%$ \\
\hline & & & & 9 & 7 & 9 & 5 \\
\hline 8 & Poland & 28 & 30 & $30 \%$ & $23,3 \%$ & $30 \%$ & $16,7 \%$ \\
\hline 0 & Frann & 2 & 20 & 8 & 10 & 9 & 1 \\
\hline 9 & rrance & $\angle 0$ & 28 & $28,6 \%$ & $35,7 \%$ & $32,1 \%$ & $3,6 \%$ \\
\hline & & & & 4 & 5 & 4 & 1 \\
\hline 10 & Belgium & 12 & 14 & $28,6 \%$ & $35,7 \%$ & $28,6 \%$ & $7,1 \%$ \\
\hline & & & & 3 & 1 & 2 & 5 \\
\hline 11 & Portugal & 11 & 11 & $27,3 \%$ & $9,1 \%$ & $18,2 \%$ & $45,4 \%$ \\
\hline & & & & 9 & 11 & 17 & 7 \\
\hline 12 & Germany & 44 & 44 & $20,5 \%$ & $25,0 \%$ & $38,6 \%$ & $15,9 \%$ \\
\hline & & & & 5 & 7 & 14 & 6 \\
\hline 13 & Ukraıne * & 31 & 32 & $15,6 \%$ & $21,9 \%$ & $43,7 \%$ & $18,8 \%$ \\
\hline
\end{tabular}

Note: DNS- did not start; DNF- did not complete the distance; DQ-disqualified. Ukraine * - the results are given taking into account 2 temporarily suspended athletes [13]

Among the athletes of the national team of Ukraine in the first eight results corresponded to only five cases $(15.6 \%)$ and at the same time $43.7 \%$ of athletes showed results below the seventeenth place, which is one of the worst results among European countries, while the team leaders have $32 \%$ to $60 \%$ of the results in the top eight. Unfortunately, also in the national team of Ukraine almost $19 \%$ of the total number of representatives of endurance running could not finish their distances under various circumstances (DNF, DQ), while in the leading countries in endurance, this figure fluctuates in ranging from $3.6 \%$ to $11.4 \%$.

One of the main criteria for the effectiveness of each athlete and sports team as a whole is the ability of sports professionals to prepare the athlete for the highest level of "sports form" during the performance at the "main competition of the year", namely the ability to set a personal record. Additionally, the information obtained on the performance of athletes in endurance at the European Championships in Berlin from the standpoint of this evaluation criterion was analyzed (Table 4). 
Table 4

The results of the performance of athletes in accordance with the level of personal achievement following the XXIV European Athletics Championships (Berlin, 2018)

\begin{tabular}{|c|c|c|c|c|}
\hline Place & Team & Participants & $\begin{array}{c}\text { Total PB }+1.5 \% \\
\text { deviation }\end{array}$ & $\mathrm{PB}+\mathrm{SB}$ \\
\hline \multirow{2}{*}{1} & \multirow[t]{2}{*}{ Israel } & \multirow{2}{*}{4} & $3+0$ & $3+0$ \\
\hline & & & $75,0 \%$ & $75,0 \%$ \\
\hline \multirow{2}{*}{2} & \multirow[t]{2}{*}{ Spain } & \multirow{2}{*}{42} & $5+21$ & $5+4$ \\
\hline & & & $61,9 \%$ & $21,4 \%$ \\
\hline \multirow{2}{*}{3} & \multirow[t]{2}{*}{ Italy } & \multirow{2}{*}{30} & $7+11$ & $7+2$ \\
\hline & & & $60,0 \%$ & $30,0 \%$ \\
\hline \multirow{2}{*}{4} & \multirow[t]{2}{*}{ Belarus } & \multirow{2}{*}{12} & $3+4$ & $3+2$ \\
\hline & & & $58,3 \%$ & $41,7 \%$ \\
\hline \multirow{2}{*}{5} & \multirow[t]{2}{*}{ France } & \multirow{2}{*}{26} & $2+13$ & $2+3$ \\
\hline & & & $57,7 \%$ & $19,2 \%$ \\
\hline \multirow[t]{2}{*}{6} & \multirow[t]{2}{*}{ Netherlands } & \multirow{2}{*}{10} & $1+4$ & $1+1$ \\
\hline & & & $50,0 \%$ & $20,0 \%$ \\
\hline \multirow{2}{*}{7} & \multirow[t]{2}{*}{ Belgium } & \multirow{2}{*}{12} & $1+4$ & $1+0$ \\
\hline & & & $41,7 \%$ & $8,3 \%$ \\
\hline \multirow{2}{*}{8} & \multirow[t]{2}{*}{ Norway } & \multirow{2}{*}{12} & $1+4$ & $1+1$ \\
\hline & & & $41,7 \%$ & $16,7 \%$ \\
\hline \multirow{2}{*}{9} & \multirow[t]{2}{*}{ United Kingdom } & \multirow{2}{*}{35} & $4+9$ & $4+4$ \\
\hline & & & $37,1 \%$ & $22,9 \%$ \\
\hline \multirow{2}{*}{10} & \multirow[t]{2}{*}{ Ukraine * } & \multirow{2}{*}{31} & $4+6$ & $4+3$ \\
\hline & & & $32,3 \%$ & $22,6 \%$ \\
\hline \multirow[b]{2}{*}{11} & \multirow{2}{*}{ Germany } & & $4+10$ & $4+5$ \\
\hline & & 44 & $31,8 \%$ & $20,5 \%$ \\
\hline & Poland & & $4+4$ & $4+3$ \\
\hline 12 & & 28 & $28,6 \%$ & $25,0 \%$ \\
\hline & Portugal & & $1+2$ & $1+0$ \\
\hline 13 & & 11 & $27,3 \%$ & $9,1 \%$ \\
\hline & & & $40+92$ & $40+40$ \\
\hline & Total & 297 & $44,4 \%$ & $26,9 \%$ \\
\hline
\end{tabular}

Note: PB - personal record; SB - the best result of the season

The results of the analysis allow us to note that the representatives of the thirteen best teams in the European Endurance Championship, which had all the gold medals of the continental tournament, showed eighty results ( $27 \%$ of athletes), which corresponds to a personal record (RV). and the best result of the season (SB). Practical experience shows that the indicator of the best result of the season (SB) does not always reflect the high level of achievement of the athlete, especially in athletics where the duration of competitive activities is from 2 to 4 hours (marathon running, athletic walking $50 \mathrm{~km}$ ). This feature is explained by the fact that the specifics of sports training and selection for competition allows the athlete to make only 1-3 starts per year, so in most cases the result shown at the main start of the year may be the first of the season and therefore automatically becomes the best result of the season. significantly does not correspond to the level of personal record and can not qualitatively reflect the effectiveness of training and performance in competitions.

Taking into account the analysis and refraction through the prism of research by LP Matveev [2], it was confirmed that it is more appropriate to take into account the personal achievements of athletes with a deviation of up to $1.5 \%(\mathrm{~PB}+1.5 \%)$ because it corresponds to the zone 
of best and similar results, which are demonstrated in the main starts by highly qualified athletes in cyclic sports.

In our research it was proved that from $50 \%$ to $75 \%$ of athletes in the leading countries in endurance achieve a result that meets the criterion (PB $+1.5 \%)$, unfortunately in Ukrainian athletes this figure is $32.3 \%$. The average among the thirteen best teams in Europe, $44.4 \%$ of athletes reach a level that corresponds to a personal record with $1.5 \%$ deviation from it.

Summarizing the approaches to assessing the performance of a sports team in endurance in the
European Athletics Championships in Berlin, they were combined taking into account the three considered performance criteria and determined the percentage of cases that meet these criteria. The combination of these criteria makes it possible to assume that the countries that have the highest score on individual criteria have more effectively implemented the program of direct preparation for the main competition of the year. The total percentage of these criteria was taken into account as a percentage of "success rate".

Table 5

Summary of the criteria for evaluating the performance of athletes following the XXIV European Athletics Championships (Berlin, 2018)

\begin{tabular}{|c|c|c|c|c|c|c|}
\hline Place & Team & $\begin{array}{l}\text { Number } \\
\text { results }\end{array}$ & Medals & $\begin{array}{c}\text { Places 4- } \\
8 \mathrm{~m}\end{array}$ & $\begin{array}{c}\mathrm{RV}+1.5 \% \\
\text { (from } 9 \text { places } \\
\text { and below) }\end{array}$ & $\begin{array}{c}\text { Success } \\
\text { rate }\end{array}$ \\
\hline \multirow{2}{*}{1} & \multirow{2}{*}{ Belarus } & \multirow{2}{*}{$14+1$ (к) } & 3 & 4 & 3 & 10 \\
\hline & & & $20,0 \%$ & $26,7 \%$ & $20,0 \%$ & $66,7 \%$ \\
\hline \multirow{2}{*}{2} & \multirow{2}{*}{ Spain } & \multirow{2}{*}{$43+2$ (к) } & 7 & 10 & 12 & 29 \\
\hline & & & $15,6 \%$ & $22,2 \%$ & $26,7 \%$ & $64,5 \%$ \\
\hline \multirow{2}{*}{3} & \multirow{2}{*}{ Norway } & \multirow{2}{*}{14} & 4 & 2 & 3 & 9 \\
\hline & & & $28,6 \%$ & $14,3 \%$ & $21,4 \%$ & $64,3 \%$ \\
\hline \multirow{2}{*}{4} & \multirow[t]{2}{*}{ Italy } & \multirow{2}{*}{$31+2$ (к) } & 6 & 5 & 10 & 21 \\
\hline & & & $18,2 \%$ & $15,2 \%$ & $30,3 \%$ & $63,7 \%$ \\
\hline \multirow{2}{*}{5} & \multirow{2}{*}{ Israel } & \multirow{2}{*}{5} & 1 & 2 & - & 3 \\
\hline & & & $20,0 \%$ & $40,0 \%$ & - & $60,0 \%$ \\
\hline \multirow{2}{*}{6} & \multirow{2}{*}{ France } & \multirow{2}{*}{$28+1$ (к) } & 6 & 2 & 8 & 16 \\
\hline & & & $20,7 \%$ & $6,9 \%$ & $27,6 \%$ & $55,2 \%$ \\
\hline \multirow[b]{2}{*}{7} & \multirow{2}{*}{ United Kingdom } & \multirow{2}{*}{$35+1$ (к) } & 4 & 11 & 4 & 19 \\
\hline & & & $11,1 \%$ & $30,6 \%$ & $11,1 \%$ & $52,8 \%$ \\
\hline \multirow{2}{*}{8} & \multirow{2}{*}{ Belgium } & \multirow{2}{*}{14} & 2 & 2 & 3 & 7 \\
\hline & & & $14,3 \%$ & $14,3 \%$ & $21,4 \%$ & $50,0 \%$ \\
\hline \multirow{2}{*}{9} & \multirow{2}{*}{ Netherlands } & \multirow{2}{*}{12} & 2 & 1 & 3 & 6 \\
\hline & & & $16,7 \%$ & $8,3 \%$ & $25,0 \%$ & $50 \%$ \\
\hline \multirow{2}{*}{10} & \multirow{2}{*}{ Portugal } & \multirow[b]{2}{*}{11} & 1 & 2 & 2 & 5 \\
\hline & & & $9,1 \%$ & $18,2 \%$ & $18,2 \%$ & $45,5 \%$ \\
\hline \multirow[b]{2}{*}{11} & \multirow[b]{2}{*}{ Poland } & & 3 & 7 & 3 & 13 \\
\hline & & $30+1$ (к) & $9,7 \%$ & $22,6 \%$ & $9,7 \%$ & $42,0 \%$ \\
\hline & & & 1 & 8 & 9 & 18 \\
\hline 12 & Germany & $44+2$ (к) & $2,2 \%$ & $17,4 \%$ & $19,6 \%$ & $39,2 \%$ \\
\hline & & & 4 & 3 & 5 & 12 \\
\hline 13 & Ukraıne & $32+2(\mathrm{~K})$ & $11,8 \%$ & $8,8 \%$ & $14,7 \%$ & $35,3 \%$ \\
\hline
\end{tabular}

Given the fact that some athletes participated in two types of European Championship programs, as well as team competitions in marathon running (Marathon Cup), the percentage of cases was calculated not from the number of national teams, but from the number of all results shown by athletes in each country. 


\section{Discussion}

Thus, the total indicator of the relative "success rate" of the team's performance allows the most broad analysis of the performance of athletes at the main start of the season. The teams of the first six have from $55 \%$ to $67 \%$ of the results corresponding to this indicator. The national team of Ukraine has $35.3 \%$ of results and therefore among the researched results of the thirteen best countries of the European Championship in endurance ranks last, our team has several leaders who can compete for medals in the European arena, as evidenced by 4 medals won (the best indicator during the years of Independence of Ukraine in endurance) and at the same time almost two thirds of the team did not reach the level of their best results and $44 \%$ of the team's athletes took places from 17 and below. Unfortunately, the presence of two suspended athletes in the national team following the results of the European Championship is also of great concern.

According to the proposed approach to the evaluation of the performance of a sports team in athletics in endurance should take into account the following criteria:

- the first criterion "Medal", which takes into account the number of athletes who took first to third place in individual programs. According to this criterion, the highest rate of $28.6 \%$ have representatives of Norway, the worst in Germany $2.2 \%$.

- the second criterion "Seats from 4 to 8", which takes into account the number of athletes who took from fourth to eighth place in the individual types of the program. The best indicators are in the teams of Israel (40\%), Great Britain (30.6\%) and Belarus (26.7\%). Unfortunately, only $8.8 \%$ of Ukrainian athletes have one 7 th place in individual competitions and two 7th and 8th places in marathon team competitions (

- The third criterion "PB + $1.5 \% "$ characterizes the number of sports results that correspond to the level of personal record of the athlete with a deviation of $1.5 \%$ from it, which is applied to the group of participants from 9th place and below. The best according to this criterion were the teams of Italy (30.3\%), France (27.6\%) and Spain $(26.7 \%)$, while the athletes of the national team of Ukraine in twice the performance (14.7\%).

Sports theorists and practitioners emphasize the importance of taking into account the content and results of competitive activities of athletes [8, 18]. Sports practice is saturated with a significant number of methodological approaches to assessing the effectiveness of competitive activities of athletes, which is regulated by the method of determining sports results. There are sports whose success is determined by a certain number of points and points according to the judges $[5,6,7]$, at the same time there is a group of sports with an objective metric measurement of the result $[4,19,20]$. Summarizing the existing approaches to assessing the effectiveness of competitive activities should pay attention to the formation of its clear criteria.

In martial arts $[6,7]$ the effectiveness of sports activities of the athlete is determined by certain criteria of efficiency, which are regulated in accordance with the rules of competition and form the sports result. In sports, on the other hand, the sports result is determined by the sum of the points gained while counteracting the opponent. At the same time, the effectiveness of the competitive activities of each athlete in the sports team is a selection of technical and tactical actions that have an effective implementation of the game situation [10, $11,21,22]$.

According to OK Kozlova [19] understanding of the results of competitive activities in athletics is needed to determine the overall strategy of training athletes, objectification of sports results in a particular competition, increase the effectiveness of tactical training, modeling in sports training conditions of real competitions.

Most athletics, on the other hand, is characterized by the presence of an objectively measured athletic result, which can be represented as a certain amount of time or distance. At the same time, speaking about the success of the country's sports team in athletics on the world stage of competition, we should pay attention to a somewhat limited number of criteria for assessing its effectiveness. This trend does not allow in most cases to cover the performance of each athlete and take into account the personal achievements of athletes in the case when this result remained outside the top eight best results.

In the course of the research we proposed the expansion of the criteria for assessing the effectiveness of the competitive activity of the sports team in athletics in endurance. In unison with our research, the results of the work of KG Клецова, M.B. Chervonyuk [5] confirm the need to create a fundamentally new approach to the formation of national teams in the sport and further evaluation of activities on a much larger number of performance criteria.

\section{Conclusions}

The results confirm the need to expand approaches to assessing the effectiveness of the team's performance in official competitions, 
deepening the analysis of the results allows to understand why the best countries succeed, respectively to identify their shortcomings and find possible ways to improve the training system.

\section{Conflict of interest}

Authors state that there is no conflict of interest.

\section{References}

1. Tyshchenko V. Expert Control System Assessment of Training and Competitive Activities of Highly Qualified Handball Teams. Physical Education, Sport and Health Culture in Modern Society, 2016; 4(36), 104-111. (in Ukrainian).

2. Matveev LP. The general theory of sport and its applied aspects. St. Petersburg: Lan'; 2005. 384 p. (in Russian).

3. Vikhrov K. Research of professionally significant psychophysiological properties and qualities of a football referee. Theory and Methods of Physical Education and Sports, 2018; 1: 67-71. doi: 10.32652/tmfvs.2018.1.67-71. (in Ukrainian).

4. Kozlova OK, Vorobyova AB, Kosminina OS, Bogdan AO. The relevance of research is caused by decreasing of results effectiveness of Ukrainian athletes performances on the world sport arena on example of track and field. Scientific journal of NPU named after M.P. Drahomanov, 2017; 9(91): 39-43. (in Ukrainian).

5. Kletsov KG, Chervatyuk MV. Pedagogical monitoring of integrated prepared in dancesport based on analysis of competitive activity. International research journal, 2016; 10-3(52): 145-148. doi:10.18454/IRJ.2016.52.007 (in Russian).

6. Gomboev BB, Poleva NV, Zavyalov DA. Pedagogical control over a wrestler's tactical and technical preparedness at the competition stage. Bulletin of Krasnoyarsk State Pedagogical University named after V.P. Astafev, 2014; 4(30): 49-56. (in Russian).

7. Nazarenko LD, Kolesnik IP, Osipov YES. Evaluation of the effectiveness of competitive activity of boxers 13-14 years old at the stage of initial sports training. Volga region pedagogical search, 2017; 3 (21): 141-147. (in Russian).

8. Gamaliy V, Shlonska O. Evaluation of results of competitive activity in volleyball. Theory and Methods of Physical Education and Sports, 2014; 2: 3-8. [cited 2020 Apr 21]. Available from: http://nbuv.gov.ua/UJRN/TMFVS_2014_2_2. (in Ukrainian).

9. Shpichka T.Analysis of the factors of efficiency of competitive activity of qualified players in mini-football. Scientific journal of NPU named after M.P. Drahomanov, 2016; 9: 109-112. [cited 2020 Apr 16]. Available from: http://nbuv.gov.ua/UJRN/Nchnpu_015_2016_9_32. (in Russian).
10. Kostiukevych VM. Model indicators of collective interactions of highly qualified football players during the game. Health, sport, rehabilitation, 2019; 5(4): 3340. doi: 10.34142/HSR.2019.05.04.04

11. Kozina ZhL, Gushchin SA, Safronov DV, Khrapov SB, Vasilyev YuK. Identify patterns of individual dynamics of competitive performance of athletes as a basis for predicting results (qualified basketball players for example). Health, sport, rehabilitation, 2019; 5(2): 36-43. doi: 10.34142/HSR.2019.05.02.04

12. Wojciechowski SM. Fast water. Moscow: Young Guard; 1983. p. 67-72. (in Russian).

13. The site of the National Anti-Doping Center of Ukraine [Electronic resource]: according to NADCU. Available from: https://nadc.org.ua/dopingkontrol/tymchasovo-vidsotoneni-sportsmeny/

14. https://www.tilastopaja.eu/

15. http://atfs.org

16. https://www.european-athletics.org

17. http://uaf.org.ua

18. Platonov VN. The system of training athletes in Olympic sports. General theory and its practical applications: a textbook [for trainers]: in 2 books. Kiev: Olympic literature; 2015.770 s. (in Russian).

19. Kozlova O. Competitive activity of athletes of high qualification in different disciplines of athletics. Theory and Methods of Physical Education and Sports, 2014; 3: 13-19. [cited 2020 Apr 20]. Available from: http://nbuv.gov.ua/UJRN/TMFVS_2014_3_4. (in Ukrainian).

20. Science and Sport: a collection of review articles. Ed. V.M. Zatsiorsky, G.S. Tumanyan. M .: Progress; 1982. 270 p. (in Russian).

21. Kostiukevych V, Imas Y, Borysova O, Dutchak M, Shynkaruk O, Kogut I, Voronova V, Shlonska O, Stasiuk I. Modeling of the athletic training process in team sports during an annual macrocycle. Journal of Physical Education and Sport, 2018; 18(S.1): 327-334. doi:10.7752/jpes.2018.s144

22. Melnik, A. The analyses of efficiency of a power serve in jump depending on the accuracy of its performance in the competitive activity of volleyball players. Slobozans kij naukovo-sportivnij visnik [Slobozhanskyi herald of science and sport], 2016; 5: 53-56. doi:10.15391/snsv.2016-5.010. (in Ukrainian). 
Information about the authors

Rykalov Iu.V.

yuriy.rykalov@gmail.com

https://orcid.org/0000-0002-1298-2959

Secondary school №168

street Ozerna 2, Kyiv, 04209

\section{Goncharova N.M.}

nataliinfiz@gmail.com

http://orcid.org/0000-0002-3000-9044

National University of Physical Education and Sport of

Ukraine

street Physical Culture, 1, Kyiv, 03150, Ukraine

Received: 04.06.2020

\section{Інформація про авторів}

Рикалов Ю.В.

yuriy.rykalov@gmail.com

https://orcid.org/0000-0002-1298-2959

Середня школа №168

вул. Озерна 2, Київ, 04209

\section{Гончарова Н.M.}

nataliinfiz@gmail.com

http://orcid.org/0000-0002-3000-9044

Національний університет фізичного виховання i спорту України

вул. Фізкультури, 1, Київ, 03150, Україна

Прийнята до редакиії: 04.06.2020 